http://ejournal.uin-suska.ac.id/index.php/JETE

\title{
UPAYA MENINGKATKAN HASIL BELAJAR PESERTA DIDIK DENGAN MENGGUNAKAN MODEL DISCOVERY LEARNING PADA MATA PELAJARAN MATEMATIKA KELAS IXA SMPN 4 TAPUNG HILIR TAHUN PELAJARAN 2019/2020
}

\author{
Sri Dayanti \\ SMP Negeri 4 Tapung Hilir Kampar, Indonesia ${ }^{1}$ \\ Email: srivanti0117@ yahoo.com*1
}

\begin{abstract}
ABSTRAK
Penelitian tindakan kelas ini bertujuan untuk mendeskripsikan hasil belajar peserta didik sebelum mengikuti proses pembelajaran dengan menggunakan model discovery learning, kelas IXA SMPN 4 Tapung Hilir pada pembelajaran matematika materi Volume Kerucut; mendeskripsikan aktivitas belajar peserta didik selama peserta didik mengikuti pembelajaran dengan menggunakan model discovery learning, kelas IXA SMPN 4 Tapung Hilir pada pembelajaran matematika materi Volume Kerucut; mendeskripsikan peningkatan hasil belajar peserta didik setelah peserta didik mengikuti proses pembelajaran dengan menggunakan model discovery learning,kelas IXA SMPN 4 Tapung Hilir pada pembelajaran matematika materi Volume Kerucut. Rancangan yang ditetapkan dalam penelitian ini adalah penelitian tindakan kelas. Dalam penelitian tindakan kelas secara garis besar terdapat empat tahapan yang lazim dilalui, yaitu perencanaan, pelaksanaan, pengamatan, dan refleksi. Kondisi awal peserta didik yaitu pada saat peserta didik belum menerima pembelajaran dengan menggunakan model pembelajaran Discovery Learning. Data awal yang digunakan adalah data nilai ulangan harian peserta didik yang masih rendah dan banyak yang belum tuntas dari kriteria ketuntasan minimal (KKM), yaitu sebesar $51,72 \%$ peserta didik tidak mencapai ketuntasan. Pada hasil tes di siklus I, peserta didik yang mencapai KKM berjumlah 23 orang dengan skor tertinggi 100 sebanyak 2 orang dan skor terendah 65 sebanyak 6 orang. Dari hasil penilaian yang dilakukan pada siklus I yakni diperoleh nilai 65-71 dengan frekuensi $13(44,84 \%)$, nilai 72-78 dengan frekuensi 5 (17,24\%), nilai 79-85 dengan frekuensi 5 (17,24\%), nilai 86-92 dengan frekuensi $3(10,34 \%)$, nilai 93-100 dengan frekuensi $3(10,34 \%)$.
\end{abstract}

Kata Kunci: Penelitian ; learning; discovery; Peserta didik.

\section{EFFORTS TO IMPROVE STUDENTS 'LEARNING OUTCOMES USING DISCOVERY LEARNING MODELS IN MATHEMATICS LEARNING CLASS IXA SMPN 4 HOLIDAY IN LINE ACADEMIC YEAR 2019/2020}

\section{ABSTRACT}

This class action research aims to describe the learning outcomes of students before participating in the learning process by using the discovery learning model, class IXA 
SMPN 4 Tapung Hilir on mathematics learning material on the Cone Volume; describe the learning activities of students as long as students follow the learning by using the discovery learning model, class IXA SMPN 4 Tapung Hilir on the learning of mathematics material Cone Volume; describe the improvement in student learning outcomes after students follow the learning process by using the discovery learning model, class IXA SMPN 4 Tapung Hilir on mathematics learning material Cone Volume. The design set in this study is classroom action research. In class action research in general there are four stages that are commonly passed, namely planning, implementing, observing, and reflecting. The initial condition of students is when students have not received learning by using the Discovery Learning learning model. The initial data used is the data of students' daily test scores which are still low and many are incomplete from the minimum completeness criteria (KKM), which is equal to $51.72 \%$ of students not completing completeness. In the test results in the first cycle, students who reached KKM totaled 23 people with the highest score of 100 as many as 2 people and the lowest score of 65 as many as 6 people. From the results of the assessment conducted in the first cycle that is obtained a value of 65-71 with a frequency of 13 (44.84\%), a value of $72-78$ with a frequency of 5 (17.24\%), a value of 7985 with a frequency of 5 (17.24\%), a value of 86-92 with a frequency of 3 (10.34\%), a value of 93-100 with a frequency of $3(10.34 \%)$.

Keywords: Research; learning; discovery; Learners.

\section{PENDAHULUAN}

Mata pelajaran matematika merupakan salah satu mata pelajaran yang ada pada jenjang pendidikan Sekolah Menengah Pertama (SMP) dan tidak sedikit anak yang merasa kesulitan dalam mempelajari matematika. Kesulitan peserta didik dalam memahami matematika tersebut merupakan faktor utama yang menyebabkan peserta didik tidak menyukai pelajaran matematika. Hal ini dapat dilihat dari adanya ketidak tuntasan peserta didik kelas IX saat ulangan harian pada masing-masing kompetensi dasar. sehingga para guru matematika harus mulai mengembangkan sistim pembelajaran inofativ untuk membangkitkan minat peserta didik terhadap pelajaran matematika.

Pelaksanaan pembelajaran matematika seharusnya tidak hanya menekankan pada konsep tetapi bagaimana proses pembelajaran matematika tersebut berlangsung. Para peserta didik harus terlibat aktif dalam proses pembelajaran yaitu dalam mengajukan hipotesis, mengumpulkan data dan menggunakan bukti, merancang suatu penyelidikan melalui kegiatan percobaan dan proses-prosesnya, serta mengutamakan keingintahuan peserta didik.

Berdasarkan latar belakang masalah tersebut peneliti berpendapat perlunya dilakukan perbaikan proses pembelajaran. Pemecahan masalah di atas yang mungkin untuk dilaksanankan oleh guru adalah melaksanakan pembelajaran matematika dengan menggunakan model pembelajaran yang mengajak peserta didik untuk belajar dalam kelompok, yaitu peserta didik mengamati langsung dan menyelidiki, yang akhirnya peserta didik bisa mendapatkan hipotesis, mengumpulkan data dan membuktikan hasil uji cobanya, sehingga peserta didik mampu menemukan ide-ide baru dari suatu penemuannya dan peserta didik akan terbiasa aktif bertanya dan berpendapat. Salah satu model pembelajaran 
yang mendorong kreativitas dalam diri peserta didik diantaranya adalah model discovery learning.

Berdasarkan latar belakang dan identifikasi masalah sebagaimana telah diuraikan di atas, maka masalah yang menjadi fokus penelitian tindakan ini adalah: Apakah model discovery learning dapat meningkatkan hasil belajar peserta didik dalam materi volume Kerucut di kelas IXA di SMPN 4 Tapung Hilir tahun pelajaran 2019-2020?; Bagaimana peningkatan hasil belajar peserta didik setelah peserta didik mengikuti proses pembelajaran dengan menggunakan model discovery learning?

\section{METODE PENELITIAN}

Rancangan yang ditetapkan dalam penelitian ini adalah penelitian tindakan kelas. Menurut Arikunto dkk (2010: 16), dalam penelitian tindakan kelas secara garis besar terdapat empat tahapan yang lazim dilalui, yaitu perencanaan, pelaksanaan, pengamatan, dan refleksi.

Penelitian dilaksanakan di SMP N 4 Tapung Hilir, kelas IXA semester satu Tahun Pelajaran 2019/2020. Penelitian Siklus I dilakukan tanggal 20 Agustus dan siklus II pada tanggal 25 Agustus 2019.

Untuk mengukur ketuntasan peserta didik, maka peneliti memakai pedoman penilaian dari pusat penilaian (Depdiknas,2007:367), yaitu sebagai berikut:

$$
\text { Nilai Tes : } \quad \frac{\text { Jumlah Skor Yang Diproleh }}{\text { Jumlah }} \times 100
$$

Ketuntasan individu tercapai apabila peserta didik mencapai nilai 75 dari hasil tes. Ketuntasan klasikal tercapai apabila $75 \%$ dari seluruh peserta didik

\section{HASIL DAN PEMBAHASAN}

Kondisi awal peserta didik yaitu pada saat peserta didik belum menerima pembelajaran dengan menggunakan model pembelajaran Discovery Learning. Data awal yang digunakan adalah data nilai ulangan harian peserta didik yang masih rendah dan banyak yang belum tuntas dari kriteria ketuntasan minimal (KKM), yaitu sebesar $51,72 \%$ peserta didik tidak mencapai ketuntasan.

Pelaksanaan siklus I merupakan kegiatan awal pembelajaran, yang dilaksanakan satu kali pertemuan pembelajaran dengan alokasi waktu 2 x 40 menit menggunakan model pembelajaran Discovery Learning.

\section{a. Perencanaan Tindakan Siklus I}

Perencanaan tindakan ini bertujuan untuk memperlancar jalannya pembelajaran agar tidak mengalami hambatan dan kesulitan. Pada tahap perencanaan yang dilakukan adalah menyusun beberapa pembelajaran dan instrumen penelitian yang akan digunakan dalam tindakan dengan model pembelajaran Discovery Learning.

b. Pelaksanaan

Proses pembelajaran pada siklus I dilaksanakan pada tanggal 20 Agustus 2019 yaitu dua jam pelajaran. Sebelum memulai pembelajaran peneliti memberi salam/ucapan selamat pagi dan menanyakan kabar peserta didik, kemudian mempersiapkan dan mengecek peserta didik untuk memulai pembelajaran dengan memberikan motivasi terlebih dahulu, apersepsi, 
menyampaikan kompetensi dasar, tujuan pembelajaran, metode belajar, dan penilaian dalam pelajaran. Selanjutnya peneliti memberikan permasalahan melalui tayangan powerpoint (stimulation). Peserta didik diminta untuk mengidentifikasi masalah dan memberi jawaban sementara kesempatan untuk mengajukan pertanyaan yang terkait dengan materi (Problem Statement). Peneliti membagi peserta didik menjadi beberapa kelompok dan memberikan persoalan pada setiap kelompok (Data Collection) yang tertera di dalam LKS/LAS . Dalam kelompok, peserta didik diminta memecahkan masalahmasalah yang berkaitan dengan materi (Data Processing), kemudian mempresentasikan hasil diskusinya ke depan kelas (Verivication). Peserta didik diminta membuat kesimpulan mengenai mengenai materi yang telah dipelajari dengan penguatan dari peneliti (Generalization). Terakhir guru memberikan evaluasi untuk mengukur pemahaman materi secara individu. Dari hasil penilaian evaluasi tersebut diperoleh data hasil penilaian tiaptiap peserta didik pada siklus I, untuk lebih jelas dapat dilihat pada penjelasan dibawah ini.

Pada hasil tes di siklus I, peserta didik yang mencapai KKM berjumlah 23 orang dengan skor tertinggi 100 sebanyak 2 orang dan skor terendah 65 sebanyak 6 orang. Dari hasil penilaian yang dilakukan pada siklus I yakni diperoleh nilai 65-71 dengan frekuensi $13(44,84 \%)$, nilai $72-78$ dengan frekuensi $5(17,24 \%)$, nilai $79-85$ dengan frekuensi 5 (17,24\%), nilai 86-92 dengan frekuensi 3 (10,34\%), nilai 93-100 dengan frekuensi 3 $(10,34 \%)$. Di bawah ini merupakan tabel dan grafik distribusi data nilai berdasarkan hasil kemampuan peserta didik yaitu sebagai berikut:

Tabel 1. Distribusi Frekuensi Data Hasil Siklus I

\begin{tabular}{cccc}
\hline NO & INTERVAL & FREKUENSI & PERSENTASE \\
\hline 1 & $65-71$ & 13 & $44.84 \%$ \\
2 & $72-78$ & 5 & $17.24 \%$ \\
3 & $79-85$ & 5 & $17.24 \%$ \\
4 & $86-92$ & 3 & $10.34 \%$ \\
5 & $93-100$ & 3 & $10.34 \%$ \\
& JUMLAH & $\mathbf{2 9}$ & $\mathbf{1 0 0 \%}$ \\
\hline
\end{tabular}

Grafik 1 : Hasil Tes Siklus I

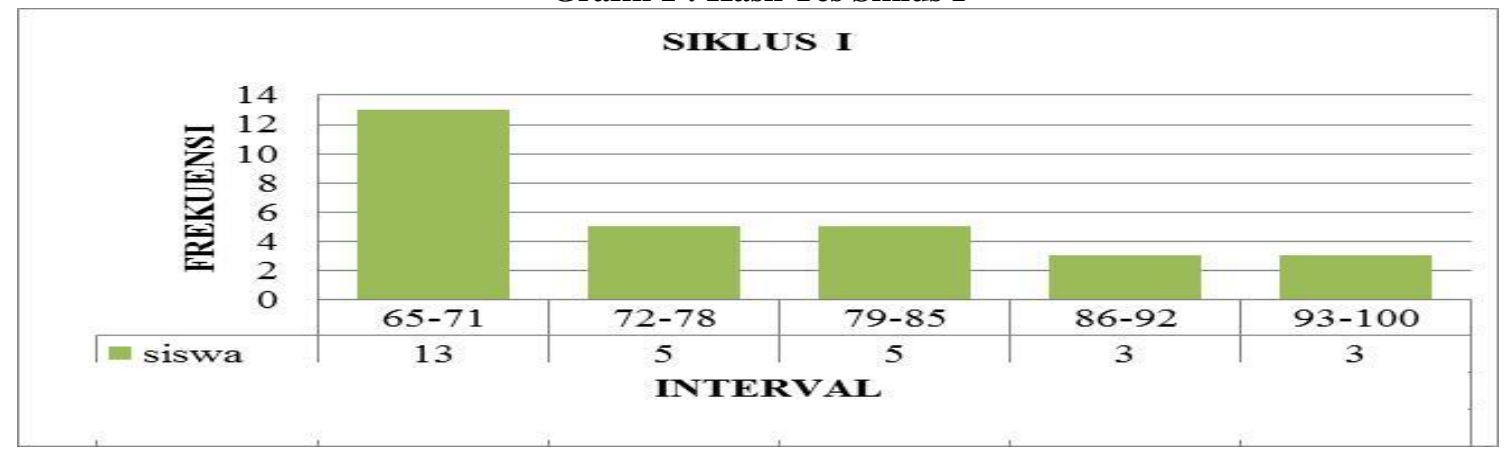


Berdasarkan tabel dan grafik di atas, jika dibandingkan dengan hasil yang dicapai peserta didik pada ulangan harian sebelum menggunakan model pembelajaran Discovery Learning, jumlah peserta didik yang mencapai nilai KKM meningkat dari 14 peserta didik menjadi 23 peserta didik dari total peserta didik 29 orang.

Selanjutnya, peneliti menyajikan persentase nilai rata-rata hasil belajarsiklus I peserta didik dan persentasi ketuntasan klasikal

Tabel 2. Rekapitulasi Hasil Belajar Siklus I

\begin{tabular}{clc}
\hline No & Uraian & Hasil \\
\hline 1 & Nilai Rata-rata & 76,72 \\
2 & Jumlah Peserta Didik yang Tuntas Belajar & 23 \\
3 & Presentase Ketuntasan Belajar Klasikal & $79,31 \%$ \\
\hline
\end{tabular}

Dari Tabel 3.3, dapat dijelaskan nilai rata-rata yang memperoleh adalah 76,72 dan ketuntasan belajar klasikal mencapai $79,31 \%$ atau dari 29 peserta didik ada 23 peserta didik yang tuntas belajar. Hasil tersebut menunjukkan bahwa pada tindakan siklus I secara klasikal peserta didik sudah tuntas belajar, karena peserta didik yang memperoleh nilai $\geq 75$ mencapai $76,72 \%$ melebihi dari presentase yang dikehendaki yaitu sebesar $75 \%$, maka tidak perlu dilanjutkan pada tindakan siklus selanjutnya.

c. Observasi

Observasi tindakan dilakukan selama proses pembelajaran berlangsung, Lembar observasi digunakan untuk mengumpulkan data mengenai sikap peserta didik dalam diskusi kelompok. terdapat enam indikator sikap yang dinilai. ( terlampir )

d. Refleksi

Berdasarkan hasil observasi dan hasil tes hasil siklus I, hasil belajar peserta didik sudah meningkat begitu pula dengan aktivitas belajar peserta didik sudah meningkat sesuai dengan rencana pembelajaran. Karena ketuntasan belajar peserta didik sudah tercapai. Dengan menggunakan model pembelajaran Discovery Learning pada pelajaran matematika, diperoleh bahwa hasil belajar meningkat. Hal ini tampak dari hasil tes yang dilakukan setelah akhir pelaksanaan siklus Ketuntasan belajar klasikal peserta didik 79,31\% .

\section{Pengujian Pertanyaan Penelitian}

Berdasarkan data yang diperoleh pada siklus I peserta didik yang tuntas sebanyak 23 peserta didik atau (79,31\%), dan tidak tuntas 6 peserta didik atau (20,69\%). Untuk lebih jelas mengenai peningkatan hasil belajar peserta didik dapat dilihat keterangan pembelajaran peserta didik sebelum dan sesudah menggunakan model pembelajaran Discovery Learning pada tabel .

Tabel 3 Perbandingan Hasil belajar peserta didik sebelum dan sesudah menggunakan model pembelajaran Discovery Learning

\begin{tabular}{cccc}
\hline Kategoori & Pretest & Siklus I & Ket \\
Tuntas & $14(48,28 \%)$ & $23(79,31 \%)$ & Adanya \\
Tidak Tuntas & $15(51,72 \%)$ & $6(20,69, \%)$ & peningkatan \\
\hline
\end{tabular}




\begin{tabular}{l}
\hline Jumlah $29(100 \%)$ \\
\hline Dari tabel di atas, dapat disimpulkan pada pretest, peserta didik yang tuntas sebanyak \\
5 orang, dan yang tidak tuntas sebanyak 15 orang, dan siklus I peserta didik yang tuntas \\
sebanyak 15 orang, dan tidak tuntas 5 orang, dengan pembelajaran terdapat peningkatan \\
$50 \%$.
\end{tabular}

\section{Pembahasan}

Hasil penelitian yang dilakukan di SMP Negeri 4 Tapung Hilir menunjukan bahwa hasil belajar matematika materi volume kerucut setelah diterapkan tindakan yaitu pembelajaran dengan menggunakan model pembelajaran Discovery Learning cenderung mengalami peningkatan dengan rata-rata tertinggi 76,72. Berdasarkan peningkatan tersebut menunjukan bahwa pembelajaran menggunakan model pembelajaran Discovery Learning dapat meningkatkan hasil belajar siswa.

Pembelajaran dengan menggunakan model Discovery Learning mengharuskan siswa untuk bekerjasama dan aktif dalam proses pembelajaran, selain itu model pembelajaran Discovery Learning menimbulkan rasa senang pada peserta didik, karena tumbuhnya rasa menyelidiki dan berhasil, peserta didik akan mengerti konsep dasar dan ide-ide lebih baik, peserta didik belajar dengan memanfaatkan berbagai sumber belajar, dan membantu peserta didik untuk mengembangkan dan memperbanyak penguasaan keterampilan dalam proses kognitif peserta didik, mampu memberikan kesempatan kepada peserta didik untuk berkembang dan maju sesuai dengan kemampuan masing-masing dan dapat membantu peserta didik untuk memperkuat dan menambah kepercayaan pada diri sendiri dengan proses penemuan.

Peneliti sebagai pelaku tindakan berupaya melatih dan membangkitkan keaktifan peserta didik dalam mengikuti kegiatan pembelajaran guna meningkatkan hasil belajar peserta didik dengan dengan menggunakan model pembelajaran Discovery Learning.

Tujuan dari penelitian ini yaitu meningkatkan hasil belajar peserta didik. Indikator yang di nilai dalam penelitian ini adalah hasil belajar peserta didik dengan nilai belajar memenuhi KKM $(\mathrm{KKM} \geq 70)$.

Penerapan pembelajaran matematika melalui model pembelajaran Discovery Learning memberikan hasil, terjadinya peningkatan hasil belajar peserta didik, dilihat dari indikator bahwa sebelum penelitian tindakan dilakukan peserta didik yang hasil belajarnya memenuhi KKM sebanyak 14 orang $(48,28 \%)$. Pada siklus I, yang hasil belajarnya memenuhi KKM sebanyak 23 orang $(79,31 \%)$.

\section{KESIMPULAN}

Hasil dari penelitian yang dilakukan dalam upaya meningkatkan hasil belajar siswa dengan menggunakan model pembelajaran Discovery Learning dapat dibuat kesimpulan sebagai berikut: Hasil belajar peserta didik kelas IXA SMP Negeri 4 Tapung Hilir dalam mengikuti proses pembelajaran matematika mengalami peningkatan setelah diterapkannya model pembelajaran Discovery Learning; Berdasarkan hasil yang diperoleh bahwa peserta didik yang hasil belajarnya memenuhi KKM sebelum dilakukan tindakan adalah sebanyak sebanyak 14 peserta didik $(48,28 \%)$ setelah dilaksanakan penelitian hasil belajar peserta didik mengalami peningkatan hasil belajar, terbukti pada akhir siklus I sebanyak 23 peserta didik $(79,31 \%)$ nilainya memenuhi KKM. 


\section{DAFTAR PUSTAKA}

Arikunto, S. (2010). Penelitian Tindakan Kelas. Jakarta: Bumi Aksara

Depdiknas. (2007). Sistem Pendidikan Nasional. Jakarta: Departemen Pendidikan Nasional.

Mukrimah, Sifa Siti. 2014. 53 Metode Belajar Pembelajaran. Bandung. Bumi Siliwangi.

Iskandarwassid. 2009. Strategi Pembelajaran Bahasa. Bandung: PT Remaja Rosdakarya.

Arikunto, S. 2008. Penelitian Tindakan Kelas. Jakarta: Bumi Aksara. 